\title{
Seven Habit Reflection In Sad Ripu (Proactive Versus Kama)
}

\author{
Kadek Ayu Ariningsih ${ }^{1}$, I Nyoman Anom Fajaraditya Setiawan ${ }^{2}$, Made Leo Radhitya ${ }^{3}$ \\ \{ayuari@stiki-indonesia.ac.id ${ }^{1}$, anomkojar@stiki-indonesia.ac.id ${ }^{2}$, leo.radhitya@ stiki- \\ Indonesia.ac.id $\left.{ }^{3}\right\}$ \\ 1,2,3 STMIK STIKOM Indonesia, Indonesia
}

\begin{abstract}
The Seven Habits of Highly Effective People are implemented by modern society to foster personal quality. Seven habits have universal leadership values. Adopting the concept of pyramid structure, Proactive is the most basic part of the three parts of the habits discussed. Proactive, emphasizing character change by training the thinking paradigm. The Balinese Hindu community adopted Sad Ripu as a leadership concept inherent in culture and habits. Seven Habits and Sad Ripu have similarities in idioms, even though they are applied to different societies and cultures. The discussion, proactive and kama reflections are judged based on literature study methods, comparing patterns of meaning that emerge.. The discourse on proactive and kama reflection raises assumptions about the major topics discussed.
\end{abstract}

Keywords: Reflection, Seven Habit, Sad Ripu, Proactive, Kama

\section{Introduction}

In human life, behavior often influences daily habits. Behavior also influences social interaction. The point of view of evaluating characteristics in lay social interaction is assessed from the procedures and ethics of a person in interacting. The influence of habits on life in society, depends on various factors on the environment of the individual. Habit factors can unwittingly influence behavior in various conditions and interactions with others.

Human civilization in different eras seems to realize the importance of managing behavior to grow habits. Human behavior and characteristics also influence culture in various places. Seven habits in the discourse characteristics and habits of life, focusing on selfleadership through a paradigm shift of thinking, from the negative to the positive, from complaining to the finding solutions.. In religious relations, especially in Bali, Seven habits have similarities with the teachings of Hindu leadership, namely Sad Ripu. The application of Sad Ripu has been going on for a long time and is applied symbolically in religious rituals called "Metatah" ceremonies.

The Seven Habits of Highly Effective People written by Stephen R. Covey which was first published in 1989 were very well reviewed by those who applied them in the world of work. The modern world changes the paradigm of human thinking. The demands of professionalism want higher speed and accuracy, which causes humans to be vulnerable to internal and external conflicts. A proactive approach is offered as a long-term solution. Proactively practicing the thinking paradigm in order to be able to apply leadership to oneself and transmit it to the surrounding environment. 
When the western world talks about the Seven Habits, Hindu civilization has first known the Book of Niti Sastra, the Book of Niti Sastra contains concepts of leadership based on Hinduism. The Book of Niti Sastra was written by Maharsi Canakya, he was a conceptor of the government system of the kingdom of Magada in India who lived in 321-296 AD (Suhardana, 2008). In the history of the development of Niti Sastra, Niti Sastra by Maha Patih Gajah Mada was used as an idea, thought about ethics and morality that must be possessed by a leader. One such idea is Sad Guna Wiweka which in Bali is called Sad Ripu. Sad Ripu is interpreted as six enemies or weaknesses in human beings that must be overcome. The six enemies or weaknesses include Kama (desire), Lobha (greediness), Krodha (anger), Moha (confusion), Mada (intoxication), Matsarya (envy). Specifically in Kama, self-control is done by training the mind to obtain better personal qualities.

Based on the description above, proactive and kama seem to have the same concept and reflect on one another, where the focus of the discussion refers to training the mind for personal character development, even though it comes from two different societies. Proactive and kama need to be explored further through scientific methods to find similarities and differences both in terms of the concept and its application so that it can answer the form of reflection between proactive and kama.

\section{Method}

This research first examines and describes habits that develop and influence people's lives. Habits as a meeting point of knowledge, skills, and desires (Rahayu, 2015) which will establish the order of life and mindset of the people involved in it. After the publication of Seven Habits (by Covey), modern society acquires knowledge, skills, and desires that help in the formation of personal character in order to reach the standards set by each individual. Whereas in the life of the Balinese Hindu community, habits are strongly rooted in the strength of adat and culture as outlined in various religious ritual activities.

Seven Habit is a guideline in improving self-quality in this modern era. Seven habits is a very extraordinary concept if it is truly applied to the education system because it will be able to produce extraordinary resources and can be said to be of high quality both in terms of knowledge and character which is fostered through habits developed in one's environment from an early age (Hendriyanto, 2018). The first part of seven habits is to be proactive. 


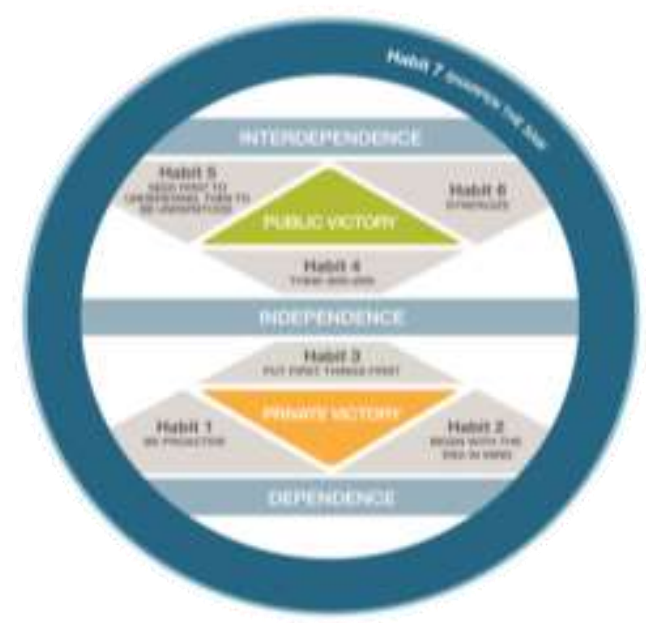

Fig 2. The 7th Habits Of Higly Effective People (Stephen R. Covey).

Figure 2. shows the seven habits section, proactively becoming the first habit. Proactivity is the opposite of reactive attitude, where everything starts with complaining, blaming the situation, negative prejudice. This proactive approach was made to change everything, emphasize the importance of changing paradigms for better thinking, seeing things from all sides and having the ability to control ourselves to face even the worst conditions. Being proactive is more than just taking the initiative. Being proactive means being responsible for our own behavior, both in the past, present and in the future. Being proactive also means being able to make choices based on the principles and values that applied in the social environment such as family, community and professional world (Dunamis, 2019).

Hinduism has a great civilization in the history of human development. Hindu values regarding leadership are expressed through the Book of Niti Sastra by Maharsi Canakya in building the kingdom of Magada in India. In Indonesia, the concept the Book of Niti Satra was applied by Maha Patih Gajah Mada in raising the Majapahit kingdom. The concept of Niti Sastra is translated into an idea of thought about the ethics and morality of a leader so that it can be an example for the community. There are 18 (eighteen) ideas, one of which is Sad Guna Wiweka. In Bali, Sad Guna Wiweka is better known as Sad Ripu. The symbolization of the practice of Sad Ripu in Balinese Hindu society is outlined in the form of yadnya ceremony, namely "metatah" which has been carried down for generations in the life of the Balinese Hindu community.Metatah is a series of rituals honing the teeth of a child who has been considered an adult, marked by the first menstruation for women, and changes in body shape that are influenced by hormonal factors for boys. Teenagers are prone to delinquency due to lack of self-control. Self-control can be defined as an activity of controlling behavior. Habits formed teenagers to have the ability to organize, guide, organize and direct forms of behavior that can lead individuals towards positive consequences (Aviyah, 2014). Metatah ritual thought to help a person to gain strength to support humans in gaining wisdom and good qualities more (suggestion to the philosophical understanding of Metatah). Kekawin Nitisāstra mentions that there is no enemy beyond the enemy in the heart of "Nora na satru mengelewihaning ana geleng ri hati" (in Budhawati, 2013). Six enemies who reside within themselves called Sad Ripu, namely Kama (desire to indulge lust), Lobha (greedy or greedy), Krodha (anger and revenge), Mada (drunk), Moha (Confused) and Matsarya (envy). With the 
suppression of the six enemies it is hoped that a child can have a better, smarter, independent and responsible character.

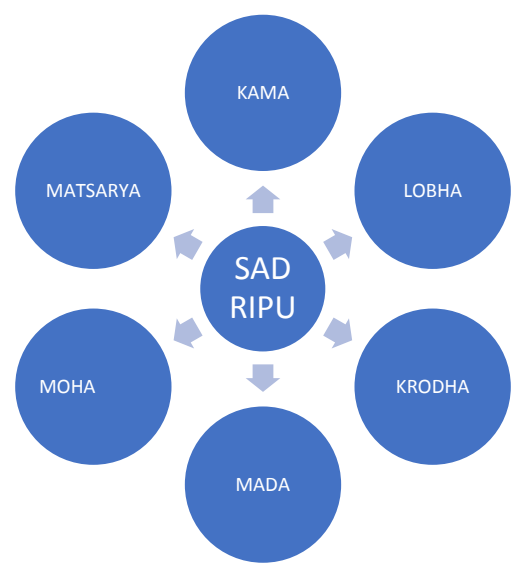

Fig 2. Sad Ripu

Figure 2 shows the parts in Sad Ripu. The first part is Kama, interpreted as "desire". Human desire is unlimited and binds humans and if not controlled then humans can do bad actions to achieve their desires. Kama can make a human grow into good or bad depending on the choice of humans themselves if it is not controlled. The universal Hindu concept conveys that Kama must be controlled by Dharma (wisdom) obtained through knowledge and experience gained both through Hindu literature such as Niti Sastra and direct experiences in social life.

This study uses the method of literature study by examining two books namely The 7 Habits of Highly Effective People (Covey, 2015) with the Book of Nitisastra (Suhardana, 2008). The study of the 2 kind of literatures includes comparison. A comparison is a form of research that compares the variables that are interconnected by expressing differences or similarities in policy and others (Meykalyan, 2016). Variables that were compared in this study were proactive and kama so finding the analysis data of the comparative results were then described descriptively.

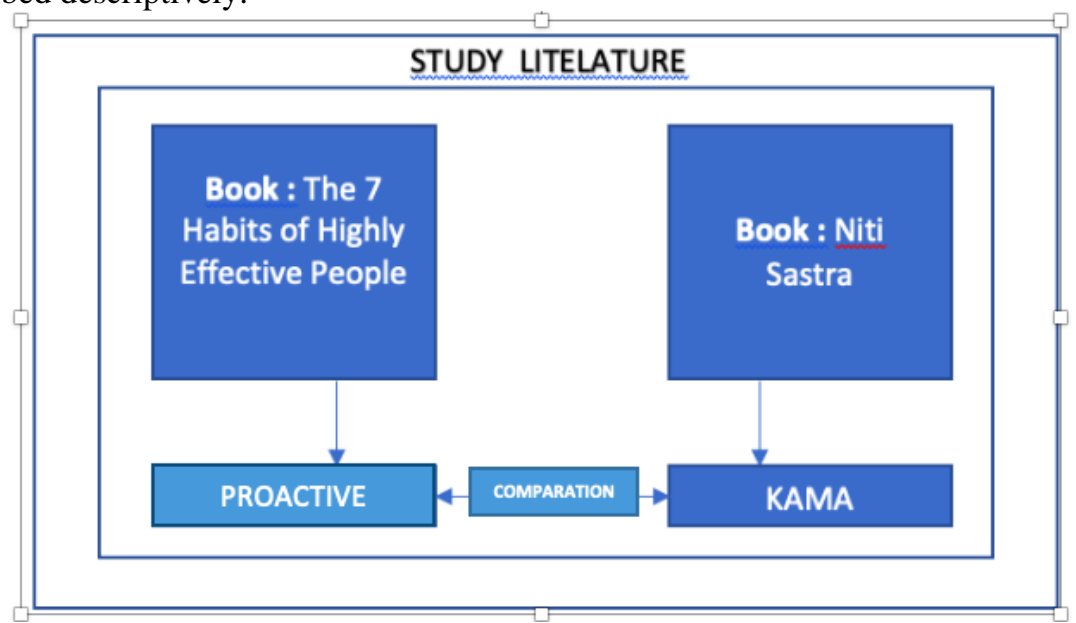

Fig 3. Research Flow 


\section{Results and Discussion}

Data from the analysis found that proactive and kama do not have a relationship, where both come from different eras and thought. Covey poured his experience and thoughts into applying his life habits in Seven Habits. Proactively raised as a habitual practice that can change the behavior of modern humans if done consistently and regularly through the process of changing the paradigm of thinking. The concept of Kama in Sad Ripu also has similarities with proactivity, the discussion of kama is self-control through mind control.

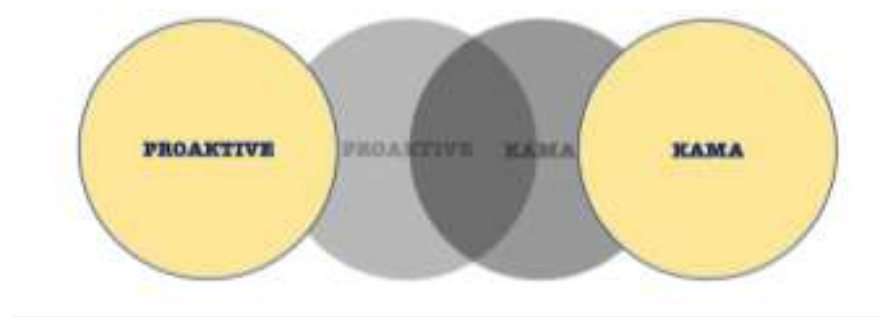

Fig 4. Proaktive and Kama Reflection

Figure 4 shows proactivity and kama have no historical background, but both of them discuss the formation of leadership character by training the mind. both reflect each other in terms of concepts, self-control, personal ethics, and knowledge of human ability to overcome conflict.

\subsection{Reflections on Concepts in Proactive and Kama}

The proactive concept relates to stimulus and response (Covey, 2015). Human behavior is a product of human conscious choice itself. The concept of kama is control over desire. The realization of a desire also depends on the conscious choices of each person.

\subsection{Reflection of Self Control in Proactive and Kama}

Opponents rather than proactive are reactive. People who do not want to train their minds will be trapped in a reactive attitude such as narrow mindedness, irritability, the ego can even cause harm to other humans control of kama will lead people to become better individuals. Actions (Kayika), Words (Wacika), and Mind (Manacika) if controlled can give good to other humans

\subsection{Reflections on Personal Ethics in Proactivity and Kama}

Personality ethics is a long-term effect of proactive attitudes needed in the world of work. Associated with personality ethics, Kama is related to self-leadership to form the character of Satwika. Humans with the character of satwika can lead and give good examples for the people they lead.

\subsection{Reflection The Ability to Dealing Conflicts in Proactive and Kama}


Balance is the result obtained by training the mind to always be proactive. Modern humans are vulnerable to conflict. This arises because it still depends on factors outside of itself. The essence of life as a human is the purpose of life. One of the goals of life is the balance between physical and spiritual fulfillment. But often there is a gap between hope and reality. Such a great desire is not in accordance with the ability to make it happen. Desires must be managed by humans themselves to avoid conflict.

Proactive and kama values can be applied in social and professional environments. Humans as social creatures will always interact with other humans. Social interaction involves various kinds of individuals with different personalities, even in the world of work there are differences in status of position that can cause greater pressure for weaker individuals. Humans will always be involved in a variety of conflict-filled activities. Humans can overcome all problems by training and controlling the mind towards better. So, this has become a habit in daily life.

\section{Conclusions}

Seven habits and sad ripu is the science of leadership to form someone who has a better character. This study provides an overview of proactive and kama comparisons when compared it turns out to find a conclusion that each other reflects each other. Another thing that is shown through this research is that humans are in accordance with their era having the ability to obtain solutions to the tendency of problems that occur around them. Leadership science described in proactive and kama is a source of guidance for those who want to develop their own character so they can lead themselves towards the future. At present the millennial generation is in industry 4.0 and industry era 5.0 will not be too long to face, to face it requires superior generations who are able to overcome various conflicts in the social and professional environment.

\section{Acknowledgments}

Acknowledgments are addressed to STMIK STIKOM Indonesia for the support and facilities provided to the authors to develop competence in the field of publication through International Conference on Local Wisdom 2018.

\section{References}

[1] Aviyah, Evi dan Farid Muhammad. Religiusitas, Kontrol Diri Dan Kenakalan Remaja. Jurnal Psikologi Remaja. Volume 3 Nomor 2 (2014)

[2] Budhawati, Ni Putu Sudewi. Upacara Potong Gigi ditinjau dari Filsafat dan Fenomena Sosial Masyarakat Hindu di Lombok. Jurnal GaneÇ Swara. Volume 7 Nomor 2 (2013)

[3] Covey, Stephen R. 2015. The Seven Habits of Highly Effective People (7 Kebiasaan yang Sangat Efektif). Jakarta: Dunamis

[4] Dunamis, 2019. Pemimpin yang Proaktif. Dalam http://www.dunamis.co.id/product/article/31 diakses tanggal 10 Juli 2019)

[5] Hamdan, Yusuf. Penerapan Konsep "7 Habits of Highly Effective People" dalam Profesi Dosen. Jurnal Komunikasi Mediator. Volume 4 Nomor 1 (2003) 
[6] Hendriyanto, Novi. Implementasi 7 Kebiasaan dalam Menghadapi Globalisasi Fakultas Ilmu Komputer Universitas Dian Nuswantoro Semarang. Jurnal SIMETRIS. Volume 9 Nomor 1 (2018).

[7] Meykalyan, R. 2016. Studi Komparasi Standar Pelayanan Minimal (SPM) Bus Trans Jogja. Yogyakarta: Atma Jaya Yogyakarta

[8] Rahayu, Mardiyatun Mugi. Pengaruh Kebiasaan Belajar terhadap Hasil Belajar Matematika. Journal of Elementary Education. Volume 4 Nomor 1 (2015)

[9] Suhardana, K.M. 2008. Nitisastra (Ilmu Kepemimpinan atau Managemen berdasarkan Agama Hindu). Surabaya: Paramita 